\title{
Peningkatan kemampuan sains anak melalui metode eksperimen penggunaan tepung sagu
}

\author{
Romi Narti \\ Universitas Negeri Padang \\ e-mail: rominarti91@gmail.com
}

\begin{abstract}
This research uses Classroom Action Research conducted in Pertiwi Kajai Kindergarten. This research was conducted for 2 months, namely as many as 2 cycles, namely cycle I consisted of 3 meetings and cycle II consisted of 3 meetings. Data collection with observations, interviews, and documentation were analyzed by percentage techniques. The results of observations on the initial conditions indicate that children's scientific abilities are still low. The implementation of the first cycle of the first meeting until the third meeting showed an increase in children's scientific abilities, but had not been able to reach the KKM so the second cycle was carried out. After the second cycle, the first meeting until the third meeting shows a significant increase in children's scientific abilities, especially in the aspect of children, can practice how to cook from the ingredients to be used. Based on these studies it can be concluded that there is an increase in children's scientific abilities through experimental methods about sago flour in Pertiwi kajai Kindergarten, West Pasaman.
\end{abstract}

Keywords: Science ability, experimental method

This is an open access article distributed under the Creative Commons Attribution License, which permits unrestricted use,
distribution, and reproduction in any medium, provided the original work is properly cited. (C)2018 by author

\section{PENDAHULUAN}

Pendidikan memiliki pengaruh yang sangat kuat dalam kehidupan manusia di masa yang akan datang. Pendidikan dapat mengembangkan berbagai potensi yang dimiliki manusia. Melalui pendidikan manusia mengembangkan kemampuan,sikap dan bentuk-bentuk tingkah laku lainnya didalam masyarakat dimana dia hidup. Pendidikan bukan hanya pemberian informasi pengetahuan pembentukan keterampilan,melainkan usaha untuk mewujudkan keinginan,kebutuhan dan kemampuan individu sehingga tercapai kepuasan dalam seluruh aspek kehidupannya,jasmani maupun rohani.

Menurut UU No.20 tahun 2003 pengertian penddidikan adalah sebuah usaha yang dilakukan secara sadar dan terencana untuk mewujudkan suasana belajar dan proses pembelajaran agar peserta didik secara aktif mengembangkan potensi dirinya untuk memiliki kekuatan spiritual keagamaan, membangun kepribadian pengendalian diri,kecerdasan,kemuliaan serta keterampilan yang diperlukan dirinya,masyarakat bangsa dan negara Indonesia.

Berk dalam Yulsyofriend (2013) menyatakan anak usia dini adalah sosok individu yang sedang menjalani suatu proses perkembangan dengan pesat dan func damental bagikehidupan selanjutnya. Anak usia dini berada pada rentang usia 0-8 tahun. Pada masa ini proses pertumbuhandan perkembangan dalam berbagai aspek sedang mengalami masa yang cepat dalam rentang perkembangan hidup manusia.

Menurut Santoso (2009) pendidikan anak usia dini merupakan usaha sadar untuk memfasilitasi pertumbuhandan perkembangan jasmani dan rohani anak, yang dilakukan melalui upaya penyediaan dan rohani anak, yang dilakukanmelalui upaya penyediaan pengalaman dan pemberian rangsangan yang kaya dan bersifat menyeimbangkan. 
Pendidikan Anak Usia Dini bertujuan membantu anak didik dalam megembangkan berbagai potensi baik psikis dan fisik yang meliputi nilai-nilai agama dan moral, sosial, emosional, dan kemandirian, bahasa, kognitif, fisik / motorik.

Pengembangan pembelajaran sains di TK salah satu terobosan penting yang perlu diperhatikan. Sains merupakan pengetahuan ilmiah yang melibatkan operasional mental, ketrampilan dan strategi yang dirancang manusia untuk pemenuhan segala kebutuhan dan keperluan hidup manusia disunia ini.

Program pengembangan pembelajaran sains ditinjau dari bidang pengembangan kemampuan yang harus dicapai, terdapa tiga dimensi yang semestinya dikembangkan bagai anak usia dini yaitu kemampuan yang terkait dengan penguasaan produ Menurut Sujiono dkk (2008) sains adalah suatu objek yang berhubungan dengan bidang studi tentang kenyataan atau fakta dan teori-teori yang mampu menjelaskan tentang fenomena alam.

Menurut Conant dalam Nugraha (20083) memberikan pengertian sains sebagai ilmu teoritis yang didasarkan atas pengamatan percobaan percobaan terhadap gejala alam makrokosmos (alam semesta) dan mikrokosmos (isi alam semesta kususnya manusia dan sifat-sifatnya).

Berdasarkan latar belakang masalah, maka dapat didefenisikan permasalahan yang muncul dalam peningkatan pengenalan sains anak melalui metode exsperimen adalah kurang berkembangnya pengenalan sains anak, kurangnya alat/media pembelajaran dalam pengembangan sains anak.

Winarno (1980) menyatakan dengan experimen dimaksudkan bahwa guru dan siswa mencoba mengerjkan sesuatu serta mengamati proses dan hasil pekerjaannya. Setelah experimennya selei anak bisa memahami peristiwa yang terjadi dan memanfaatkan hasil experimen tersebut.

Penelitian yang dilakukan dalam kegiatan ini adalah penelitian tindakan kelas. Menurut Arikunto ( 2007) bahwa penelitian tindakan kelas adalah penelitian yang dilakukan guru bekerjasama dengan peneliti atau melakukan dengan sendiri yang juga bertindak sebagai peneliti dikelas tempat peneliti mengajar dengan penekanan dan penyempurnaan peningkatan proses belajar.

Tujuan penelitian ini adalah merode exsperimen dapat mengembangkan sains anak pada TK Pertiwi Kajai Pasaman Barat. Manfaat yang diambil dari peningkatan pengenalan sain anak melalui metode exsperimen adalah bagi anak didik untuk menumbuhkan minat anak dalam mengenal sains, masukan bagi guru agar mengembangkan pembelajaran yang berkualitas, sebagai masukan bagi sekolah agar lebih merancang pembelajaran sains serta wahana dalam mengembangkan kemampuan dan mengaplikasikan ide - ide dalam menciptakan kegiatan yang menarik bagi anak untuk mencapai tujuan.

\section{METODE PENELITIAN}

Penelitian ini adalah penelitian tindakan kelas (Classroom Action Reaseaarch) menurut Kuandar (2011) penelitian tindakan kelas adalah suatu penelitian tindakan yang dilakukan oleh guru sekaligus sebagai peneliti dikelasnya atau bersama-sama dengan orang lain (kolaborasi) dengan jalan merancang, melaksanakan, dan merefleksikan tindakan secara kolaboratif dan partisipatif yang bertujuan untuk memperbaiki dan meningkatkan mutu (kualitas proses pembelajaran dikelas).

Arikunto dalam Iskandar (2011) menyatakan bahwa PTK merupakan suatu pencermatan terhadap kegiatan pembelajaran berupa sebuah tindakan, yang sengaja dimunculkan dan terjadi dalam sebuah kelas secara bersamaan.

Merajuk pendapat ahli tersebut dapat disimpulkan bahwa penelitian tindakan kelas yang dilakukan oleh guru didalam kelasnya sendiri melalui refleksi diri dengan tujuan untuk memperbaiki kinerjanya sebagai guru, sehingga hasil belajar anak meningkat penelitian tindakan kelas yang dilakukan guru merupakan suatu upaya perbaikan proses belajar dan guru tersebut juga mengembangkan kemampuan profesionalnya secara sistematis.

Subjek penelitian ini adalah anak-anak dikelompokkan B1 TK Pertiwi kajai Talamau Pasaman Barat yang berjumlah 17 orang yang akan terdiri dari 7 orang anak laki-laki dan 10 orang anak perempuan. Peneliti merupakan salah seorangguru dikelompokkan B1 ini. 
Pelaksanaan penelitian dilakukan secara bersiklus, dimulai dari siklus pertama. Hasil siklus pertama menentukan hasil siklus kedua. Setiap siklus terdiri dari beberapa langkah. Penelitian tindakan kelas terdapat empat tahap yaitu : perencanaan ( plan), tindakan (action), pengamatan (observasi), refleksi (refleksi)

Penelitian yang penulis lakukan memiliki2 siklus, yang mempunyai kegiatan yang sama. Pada siklus I dilakukannya perencanaan yaiti identifikasi masalah dan penetapan alternatif pemecahan masalah, lalu dilakukan tindakan dan pengamatan dengan melakukan observasi dengan memakai format observasi.

Siklus adalah rangkaian kegiatan kelas yang bersifat daur ulang. Pelaksanaan penelitian tindakan kelas dimulai dari siklus pertama yang terdiri dari 3 kegiatan. Apabila sudah diketahui letak keberhasilan dan hambatan dari tindakan yang dilaksanakan pada siklus I tersebut, guru menentukan rancangan untuk siklus kedua.

Bahan - bahan yang dijadikan untuk metode exsperimen diantaranya yaitu tepung sagu, santan, air, daun pisang, kelapa, gula aren, garam, pewarna makanan.

\section{HASIL}

Berdasarkan data hasil penelitian peningkatan pengenalan sains anak melalui metode exsperimen tentang sagu di taman kanak - kanak Pertiwi Kajai, diperlukan pembahasan guna memperjelas dan memperdalam kajian dalam penelitian ini. Beberapa hal yang perlu diperbaiki yaitu mengenai pembelajaran dan cara memotivasi anak agar anak senang dalam melaksanakan pembelajaran.

Pembelajaran ini dapat dilaksanakan dengan pengelolaan praktek langsung sehingga kemampuan pengenalan sains menjadi pembelajaran yang menyenangkan bagi anak. Beberapa catatan negatif yang belum teratasi pada siklus 1 dilanjutkan pada siklus II.

Pencapaian hasil yang lebih maksimal, peneliti melakukan pembelajaran pada siklus II dengan menambahkan warna pada bahan - bahannya. Hal ini dimaksudkan agar anak lebih tertarik lagi untuk melakukan metode exsperimen sehingga terjadi peningkatan keberhasilan belajar pada anak.

Berdasarkan uraian diatas menunjukkan bahwa metode exsperimen untuk meningkatkan kemampuan sains anak dapat dilihat dari tabel dan grafik dibawah ini :

Tabel 9. Hasil Observasi Peningkatan Kemampuan Sains Anak Melalui Metode Exsperimen

\begin{tabular}{clccc}
\hline No & Aspek yang diamati & $\begin{array}{c}\text { Kondisi awal } \\
(\mathbf{\%})\end{array}$ & $\begin{array}{c}\text { Siklus I } \\
(\mathbf{\%})\end{array}$ & $\begin{array}{c}\text { Siklus II } \\
(\mathbf{\%})\end{array}$ \\
\hline 1 & $\begin{array}{l}\text { Anak dapat menyebutkan } \\
\text { bahan exsperimen yang } \\
\text { akan digunakan untuk } \\
\text { pengolahan tepung sagu } \\
\text { Anak dapat menentukan } \\
\text { bahan exsperimen yang } \\
\text { akan digunakan untuk } \\
\text { pengolahan tepung sagu } \\
\text { Anak dapat } \\
\text { mempraktekkan cara- cara } \\
\text { memasak dari bahan yang } \\
\text { digunakan untuk } \\
\text { pengolahan tepng sagu }\end{array}$ & 0 & 29 & 88 \\
\hline
\end{tabular}

Berdasarkan tabel diatas dapat diketahui bahwa perkembangan kemampuan motorik halus anak dalam permainan meronce dalam kategori nilai berkembang sangat baik mengalami kenaikan.

Hasil kondisi awal pada penelitian ini diketahui bahwa pada aspek pertama, anak dapat menyebutkan bahan eksperimen yang akan digunakan, anak yang mendapat nilai berkembang sangat baik $0 \%$, keadaan ini meningkat pada hasil siklus 1 yaitu 29\% dan meningkat pada siklus II yaitu $88 \%$. Aspek kedua anak dapat menentukan bahan eksperimen yang akan digunakan pada kondisi awal tidak ada yang mendapat nilai berkembang sangat baik atau 
0\%. Meningkat disiklus I menjadi 18\% dan 94\% pada siklus II. Pada aspek ketiga anak dapat mempraktekkan cara - cara memasak tepung sagu pada kondisi awal anak mengdapat nilai 0\%, meningkat pada siklus I menjadi $29 \%$ dan $94 \%$ pada siklus II.

\section{PEMBAHASAN}

Hasil peningkatan kemampuan sain anak melalui metode eksprimen di TK. Pertiwi Kajai diperlukan pembahasan guna menjelaskan dan memperdalam kajian dalam penelitian ini. Pada kondisi awal anak masih kurang dalam sains sebagiaan besaar anak masih kesulitan dalam pengenalan sainsnya. Hal ini karena kurangnya pengelolaaan kegiatan sambil bermain sehinggaa pembelajaran tidak menyenangkan bagi anak.

Setelah melihat kondisi awal tentang peningkatan kemampuan sains anak di TK Pertiwi Kajai, peneliti melakukan tindakan untuk meningkatkan kemampuan sains anak melalaui metode eksprimen pengelolaan tepung saagu di TK Pertiwi Kajai.

Pada aspek pertama anak dapat memahami bahan eksprimen yang digunakan pada persentase kategori berkembang sangat baik pada kondisi awal $0 \%$, dan naik pada siklus satu $29 \%$ pada siklus dua $88 \%$.

Pada aspek kedua, anak dapat mengambil bahan eksprimen yang akan digunakan pada persentase kategori berkembang sangat baik padda kondisi awal 0\%, dan naik pada siklus satu 18\% pada siklus dua $94 \%$.

Pada aspek ketiga, Anak dapat mempraktikkan cara-cara memasak dari bahan eksprimen yang digunakan, pada persentase kategori berkembang sangat baik pada kondisi awal 0\%, dan naik pada sikluss satu 29\% pada siklus dua $94 \%$.

Berdasarkan uraian di atas menunjukkan bahwa peningkatan kemampuan sains anak melalui metode eksprimen pengelolaan tepung sagu meningkat, ini dapat dilihat dari tabel rata-rata pencapaian kemampuan secara keseluruhan sudah mencapai Kriteria Ketuntasan Maksimal (KKM).

Peningkatan sains anak melalui metode eksprimen pengolahan tepung sagu di TK Pertiwi Kajai terjadi peningkatan mulai dari kondisi awal, siklus I dan siklus II. Berarti metode eksprimen pengolahan tepung sagu dapat meningkatkan kemampuan sains anak di TK Pertiwi Kajai.

Dalam pelaksanaan pembelajaran peneliti memfokuskan evaluasi peningkatan sains melalui metode eksprimen pengolahan tepung sagu. Anak mampu memahami bahan eksprimen yang digunakan. Anak dapat mengambil bahan eksprimen yang akan digunakan. Anak dapat mempraktikkan cara-cara memasak dari bahan eksprimen yang digunakan.

Menurut Diknas (2002) pengenalan dini perlu dilakukan untuk menjaga terjadi nya masalah kesulitan belajar karena belum menguasai konsep sains. Maka pendidik perlu mempraktekkan cara-cara pembuatan sains kepada anak terutama pada masa usia dini.

Jadi penggunaan media yang bervariasi sangatlah berpengaruh terhadap hasil belajar anak didik, mereka tidak akan bosan terhadap media tersebut. Sedangkan eksprimen sebagai suatu media pendidikan.

Nugraha (2008) menyatakan bahwa metode eksperimen dapat memfasilitasi dan mengembangkan sikp ingin tahu, tekun, kritis, mawas diri, bertanggung jawab, bekerjasama dan mandiri dalam kehidupannya serta pengetahuan dan gagasan tentang alam sekitar dalam diri anak menjadi berkembang. Dimana anak pada usia dini ingin mencobakan bagaiman rasa menggunakan sains tentang pembuatan tepung sagu menjadi menu makanan dan dapat membebedakan cara pembutan setiap masakan yang dibuat.

\section{SIMPULAN}

Dengaan demikian berdasarkan hasil penelitian yang telah dilakukan melalui peningkatan kemampuan sains melalui eksprimen pengolahan tepung sagu di TK Pertiwi Kajai Kabupaten Pasaman Barat, mampu membuat anak didik peningkatan sainsnya melalui metode eksprimen pengolahan tepung sagu dari siklus I dan siklus II. Hal ini terlihat dari persentase hasil penelitian pada kondisi awal menunjukkan bahwa kemampuan sains anak masih rendah, dimana dapat dilihat hanya $12 \%$ anak yang mampu memenuhi KKM. Hasil penelitian pada siklus I 
dilakukan sebanyak 3 kali pertemuan, anak yang mencapai KKM pertemuan pertama adalah 24\%, pada pertemuan kedua 29\% dan pertemuan ketiga 35\%. Berdasarkan hasil tersebut maka dilakukan siklus II sebanyak 3 kali pertemuan dapat dilihat pada hasil persentase dimana anak selalu meningkat dari pertemuan pertama sampai pertemuan ketiga sehingga peningkatan kemampuan sains anak di TK Pertiwi Kajai telah mencapai KKM pada siklus II pertemuan pertama adalah mencapai $53 \%$, pada pertemuan kedua mencapai $88 \%$, pada pertemuan ketiga $94 \%$.

\section{DAFTAR PUSTAKA}

Aisyiah, Siti. (2007). Perkembangan dan Konsep Dasar Pengembangan AnakUsiaDini: Jakarta: Universitas Terbuka

Arikunto, suharsimi. Dkk. (2006.Penelitian Tindakan Kelas. Jakarta: Bumi Aksara

Izzaty. (2005). Mengenali Permasalahan Anak TK. Jakarta: Depdiknas

Iskandar. 2011). Penelitian Tindakan Kelas, Jakarta: Bumi Aksara

Kemendiknas. (2010). Pedoman pengembangan program pembelajaran di TK.Jakarta: Dirjen Dikdasmen Kemendiknas.

Kuandar. (2011). Langkah Mudah Penelitian Kelas Sebagai Pengembangan Profesi. Jakarta: Erlangga. Nugraha.Ali. (2008). Pengembangan Pembelajaran Sain Anak Usia Dini. Bandung: JILSI Foundation Poedjiadi, (1987). Sejarah Dan Filsafat Sains, Bandung:Depdikbud

Rusyan,AT,dkk. (1995). Pedoman Mengajar Ilmu Pengetahuan Alam, Jakarta: Karta Negara

Suryana, Dadan. (2013). Pendidikan Anak Usia Dini ( Teori danPraktekpembelajaran ). Padang UNP Press. Santoso. (2009). Dasar-Dasar Pendidikan TK, Jakarta: Universitas Terbuka

Sujiono, Yuliani Nuraini. (2009). Konsep Dasar Pendidikan Anak Usia Dini, Jakarta: Indek Media

Syafril. (2010). Statistia. Sukabina Press. Padang

Yeni,Indra. ( 2012). Pengantar Seni Musik Untuk Pendidikan Anak Usia Dini, Padang: Sukabina Press.

Yulsyofriend. (2013). Permainan Membaca Dan Menulis Anak Usia Dini. Padang : Sukabina Pres

Semiawan, Conny. (2009). Konsep Dasar Pendidikan Anak Usia Dini. Jakarta : Indeks

Soefendi, Indra. (2009). Strategi Pengembangan Potensi Kecerdasan Anak. Jakarta: Bee Media Indonesia

Sudaryanti. (2011). Strategi Belajar Mengajar. Jakarta: Pt. Rineka Cipta Sujana

(2004). Media Pembelajaran. Bandung : Sinar Baru Algensido

Sujiono, Yuliani, Nuraini. (2009). Konsep Dasar Pendidikan Anak Usia Dini. Jakarta : Indeks

Sumartini. (2000). Perkembangan Individu. Bandung : Alfabeta

Suyanto, Slamet. (2005 Konsep Dasar Pendidikan Anak Usia Dini. Jakarta : Depertemen Pendidikan Nasional Tedjasaputra. (2011). Bermain, Mainan Clan Permainan. Jakarta : Gramedia Widyaswarana Indonesia Tho Lai Hooong. (2008). Sains. Jakarta : Erlangga

Wijaya Kusuma. (2009). Mengenal Penelitian Tindakan Kelas. Jakarta : Malta Pritindo

Yuliani Nurani Sujiono, Dkk. (2005). Metode Pengembangan Kognitif. Jakarta Universitas Terbuka 